Roszko-Wójtowicz E., Proprzedsiębiorcza postawa obywateli - Polska na tle państw UE - próba oceny i porównania, „Ekonomia i Prawo”, Polszakiewicz B., J. Boehlke (red.), Tom XII, nr 3/2013, ss. 413-424. DOI: http://dx.doi.org/10.12775/EiP.2013.031

\author{
ELŻBIETA ROSZKO-WÓJTOWICZ*
}

\title{
PROPRZEDSIĘBIORCZA POSTAWA OBYWATELI - POLSKA NA TLE PAŃSTW UE - PRÓBA OCENY I PORÓWNANIA
}

\section{STRESZCZENIE}

Potrzeba stymulowania przedsiębiorczości w gospodarce ma istotne znaczenie $\mathrm{z}$ punktu widzenia tworzenia nowych miejsc pracy, tworzenia wartości dodanej oraz kreowania innowacji. Celem głównym niniejszego opracowania jest ocena postaw przedsiębiorczych obywateli Unii Europejskiej w latach 2003-2012. W szczególności jest to analiza sytuacji w Polsce na tle trendów panujących w pozostałych krajach członkowskich. W artykule omówiono wyniki prac Komisji Europejskiej, bardziej szczegółowo Dyrekcji Generalnej ds. Przedsiębiorstw i Przemysłu, która od roku 2000 prowadzi badania ankietowe w zakresie proprzedsiębiorczych postaw obywateli. Analiza statystyczna uwzględniała zastosowanie indeksów celem zilustrowania zmian w czasie dla wybranych zmiennych.

W wyniku przeprowadzonej analizy Autorka wykazała, że w Polsce maleje zainteresowanie zakładaniem własnej działalności gospodarczej. Jak pokazują kolejne raporty Komisji Europejskiej, ale również krajowe dane statystyczne, spada liczba podmiotów gospodarczych przypadających na 10 tys. mieszkańców.

Słowa kluczowe: przedsiębiorczość, UE-27, rozpoczynanie działalności gospodarczej Klasyfikacja JEL: L26, J24

* Elżbieta Roszko-Wójtowicz, Uniwersytet Łódzki, Wydział Ekonomiczno-Socjologiczny, Katedra Statystyki Ekonomicznej i Społecznej, tel.: +48 606661 828, e-mail: eroszko33@ gmail.com. 


\title{
PRO-ENTREPRENEURIAL MINDSETS OF CITIZENS - POLAND AND THE EU - THE ATTEMPT OF EVALUATION AND COMPARISON
}

\author{
SUMMARY
}

The development of entrepreneurship provides substantial benefits, both economically and socially all over the world. The necessity to stimulate entrepreneurship in the economy is of a crucial importance due to the creation of new working places, valueadded and the establishment of innovations. The main aim of this paper is to evaluate the entrepreneurial attitude of the EU citizens in the years 2007-2012. In particular, it puts forward a comparative analysis - Poland vs. other member states. In this paper the outcomes of empirical research undertaken by the European Commission's Directorate-General "Enterprise and Industry" were presented. This institution has been studying the development of entrepreneurship in the EU Member States and other selected countries for over a decade starting from the year 2000 relying on the opinions collected through self-constructed questionnaires. In the analytical reports entrepreneurial mindsets of citizens are discussed. In the statistical analysis various forms of indices were applied in order to show how variables were changing throughout the given period.

Given the theoretical and empirical research, it can be concluded that EU citizens are less attracted by starting their own business. According to the European Commission research, as well as the national statistics of Poland, the number of enterprises per ten thousand inhabitants is decreasing.

Keywords: entrepreneurship, EU-27, starting a business

JEL Classification: L26, J24

\section{WSTĘP}

Jednym z głównych wyzwań, jakie stoi przed Unią Europejską, jest podjęcie działań, które w konsekwencji przyczynią się do promocji i zwiększenia działań przedsiębiorczych w krajach członkowskich. Wsparcie przedsiębiorczości było jedną z głównych kwestii podjętych w ramach Strategii Lizbońskiej $^{1,}$. W dokumencie tym zapisano, iż konieczne są zmiany zmierzające do

${ }^{1}$ Plan rozwoju Unii Europejskiej przyjęty przez Radę Europejską na posiedzeniu, które odbyło się w Lizbonie w roku 2000; European Communities, Facing the Challenge. The Lisbon Strategy for Growth and Employment, Report from the High Level Group, Office for Official Publications of the European Communities, Luxembourg 2004, http://europa.eu.int/comm/lisbon strategy/index_en.html s.28-30. 
uproszczenia procedur związanych z zakładaniem własnej działalności gospodarczej. Kolejno Strategia Lizbońska zakładała tworzenie sprzyjających warunków dla powstawania i rozwoju firm innowacyjnych, szczególnie w grupie MŚP oraz stymulowanie przedsiębiorczości. Rada Europejska szczególnie zwracała uwagę między innymi na konieczność:

- skrócenia czasu, jaki wiąże się z uruchomieniem podmiotu gospodarczego,

- obniżenia kosztów z tytułu zakładania przedsiębiorstwa,

- opracowywania wieloletnich programów stymulujących rozwój przedsiębiorstw i przedsiębiorczości,

- łatwiejszy i pełniejszy dostęp do danych statystycznych, szczególnie istotnych $\mathrm{z}$ punktu widzenia przedsiębiorcy,

- przegląd instrumentów finansowych².

W dobie postępującego kryzysu gospodarczego potrzeba stymulowania przedsiębiorczości w gospodarce ma istotne znaczenie. Dodatkowo zaprojektowany Plan Działania na Rzecz Przedsiębiorczości do Roku 2020 wymusza potrzebę ponownego spojrzenia na problem zmniejszającego się zainteresowania obywateli prowadzeniem własnej działalności gospodarczej i dotowania nowych instrumentów wsparcia do aktualnej sytuacji rynkowej ${ }^{3}$. Celem głównym niniejszego opracowania jest ocena postaw przedsiębiorczych obywateli Unii Europejskiej w latach 2003-2012. Cel szczegółowy stanowi porównanie proprzedsiębiorczych zachowań mieszkańców Polski do pozostałych państw członkowskich w latach 2007-2012. W odniesieniu do tak sformułowanych celów w artykule omówiono wyniki prac Komisji Europejskiej, bardziej szczegółowo Dyrekcji Generalnej ds. Przedsiębiorstw i Przemysłu prowadzącej od roku 2000 badania ankietowe, których wynikiem są cykliczne publikacje pt. Flash Eurobarometer Survey on Entrepreneurship. W wyniku przeprowadzonej analizy Autorka wykazała, że w Polsce maleje zainteresowanie zakładaniem własnej działalności gospodarczej. Jak pokazują kolejne raporty Komisji Europejskiej, ale również krajowe dane statystyczne, spada liczba podmiotów gospodarczych przypadających na 10 tys. mieszkańców. W konsekwencji sytuacja na rynku pracy jest również mniej korzystna, spada ogólna liczba ofert pracy oraz więcej jest osób przypadających na jedną ofertę.

2 Opracowano na podstawie - Presidency conclusions. Lisbon European Council 23 and 24 March 2000, http://www.europarl.europa.eu/summits/lis1_en.htm (10.03.2013).

3 Szczegółowe omówienie problemu znajduje się w dokumencie Komisji Europejskiej pt. „Plan Działania na Rzecz Przedsiębiorczości do Roku 2020” opracowany 9 stycznia 2013 roku http://eur-lex.europa.eu/LexUriServ/LexUriServ.do?uri=COM:2012:0795:FIN:PL:PDF. 


\section{POZIOM PRZEDSIĘBIORCZOŚCI - POLSKA NA TLE UE}

Rozwój przedsiębiorczości jest ważny, gdyż towarzyszy mu tworzenie nowych miejsc pracy, wzrost konkurencyjności oraz rozwój ekonomiczno-społeczny. Przedsiębiorczość ma pozytywny wpływ na osobistą satysfakcję z życia zawodowego oraz pomaga w dążeniu do realizacji celów o wymiarze społecznym. Przejawy przedsiębiorczości w społeczeństwie są wypadkową wielu czynników, zarówno finansowych, kompetencyjnych, jak i społeczno-ekonomicznych.

Debata publiczna zapoczątkowana w roku 2003 publikacją Przedsiębiorczość w Europie. Zielona Księga odnosiła się do dwóch kwestii zasadniczych, tj. niskiego odsetka mieszkańców UE zakładających własne przedsiębiorstwa oraz niewielkiej liczby przedsiębiorstw o potencjale wzrostowym ${ }^{5}$. W odpowiedzi na problemy sformułowane w Zielonej Księdze, Komisja Europejska kontynuuje prace badawcze $\mathrm{w}$ zakresie zainteresowania obywateli UE tworzeniem i prowadzeniem własnej działalności gospodarczej. Jak już poprzednio wspomniano, efektem tych prac są raporty ukazujące się cyklicznie od roku 2000. W raportach zaprezentowane zostały zagadnienia odnoszące się do rozwoju przedsiębiorczości, postaw przedsiębiorczych, co i w jakim stopniu ma na nie wpływ oraz jakie czynniki decydują o tym, że ludzie decydują się podjąć ryzyko towarzyszące prowadzeniu własnej działalności gospodarczej i stać się przedsiębiorcami. Dodatkowo, w opracowaniach omówione zostały tak ważne problemy jak: stosunek społeczeństwa wobec przejawów przedsiębiorczości, edukacja przedsiębiorcza, podejmowanie ryzyka, rozpoczynanie działalności gospodarczej, przeszkody wobec postaw przedsiębiorczych oraz niepowodzenia w biznesie.

W badaniu ankietowym Eurobarometru ${ }^{6}$, które swym zasięgiem objęło mieszkańców krajów europejskich i wybranych krajów z innych kontynentów,

${ }^{4}$ Zielone Księgi (ang. Green Paper) to wydawane przez Komisję Europejską dokumenty, o charakterze sektorowym, obejmują wąski, specjalistyczny obszar integracji w ramach Wspólnot Europejskich. Mają najczęściej formę komunikatu, a ich podstawowym celem jest zainicjowanie dyskusji lub też całego procesu konsultacji na tematy związane $\mathrm{z}$ wybranym problemem. Zielone Księgi nie zawierają projektów konkretnych rozwiązań legislacyjnych. Wszelkie konsultacje, które są zapoczątkowane wydaniem Zielonej Księgi mogą zostać sfinalizowane poprzez wydanie Białej Księgi.

${ }^{5}$ European Communities, Green Paper. Entrepreneurship in Europe, COM(2003) 27 final, Brussels 21.03.2003, http://eur-lex.europa.eu/LexUriServ/site/en/com/2003/ com2003_0027en01.pdf, s. 8-9.

${ }^{6}$ Wszystkie edycje raportów poświęcone są zagadnieniom rozwoju przedsiębiorczości, metodom, które napędzają przedsiębiorczy sposób myślenia oraz czynnikom, które zachęcają ludzi 
problem przejawów przedsiębiorczości wśród obywateli został szeroko przedstawiony. Weryfikacji poddawane są motywy, wybory, doświadczenia oraz trudności związane z prowadzeniem własnej działalności gospodarczej. Wyniki badania wykorzystywane są przez polityków celem lepszego zrozumienia problemów związanych z rozwojem postaw przedsiębiorczych i jednocześnie są pomocne przy formułowaniu zmian w obowiązujących przepisach prawa. Ostatnie z badań zostało przeprowadzone w roku 2012 na próbie ponad 42 tys. respondentów z 40 krajów, poprzednie w roku 2009 i wzięło w nim udział 26 tys. osób zamieszkujących 36 państw. W obu badaniach udział wzięli mieszkańcy 27 państw członkowskich, krajów EFTA (Norwegia, Islandia oraz Szwajcaria), Turcji i Chorwacji. Wzorem lat ubiegłych badaniem objęto również mieszkańców Stanów Zjednoczonych Ameryki, po raz pierwszy w badaniu udział wzięli przedstawiciele wybranych krajów azjatyckich - Japonii, Korei Południowej oraz Chin ${ }^{7}$. W najnowszym badaniu dodatkowo pojawili się respondenci pochodzący z Brazylii, Izraela, Indii oraz Federacji Rosyjskiej.

W chwili obecnej Polska nie należy do krajów najbardziej przedsiębiorczych, wyprzedzają ją i to znacznie takie kraje, jak: Czechy - 87, Grecja - 74,2 i Portugalia - 70,2. Poziom przedsiębiorczości w Polsce $(37,9)$ znajduje się na poziomie nieco poniżej średniej UE $(40,7)$ i oznacza, że w naszym kraju na tysiąc mieszkańców przypada niespełna 40 podmiotów gospodarczych. Polska z uzyskanym wynikiem znalazła się w grupie 13 innych państw członkowskich, w których wskaźnik liczby przedsiębiorstw w przeliczeniu na 1 tys. mieszkańców był poniżej średniej unijnej.

Warto jednak podkreślić, że znacznie lepiej wypada Polska pod względem dwóch innych wskaźników mierzących poziom przedsiębiorczości, tj.:

- odsetka osób dorosłych, które założyły własną firmę lub podejmują działania w tym kierunku (2012 - 25\% - PL, 23\% - UE; 2009 - 23,3\% - PL, 22,2\% - UE) $)^{8}$

do stania się przedsiębiorcami. Omawiane w raporcie dane dotyczą stosunku obywateli wobec przedsiębiorczości, edukacji przedsiębiorczej, podejmowania ryzyka, tworzenia przedsiębiorstw, przeszkód w podejmowaniu działań przedsiębiorczych i niepowodzeniom w prowadzeniu własnego biznesu. W roku 2009 badaniem zostało objętych łącznie 19635 osób z krajów UE-27, w tym 1005 obywateli Polski, podczas gdy w roku 2012 w badaniu uczestniczyło 42080 osób w tym z Polski 1000 W pierwszej edycji, tj. w 2000 roku uczestniczyło 8347 osób z krajów UE-15 oraz USA. Polska uczestniczy w niniejszych badania ankietowych od roku 2004.

${ }^{7}$ Flash Eurobarometer, Entrepreneurship in the EU and beyond. Analytical Report, Series 283, 2009, http://ec.europa.eu/enterprise/policies/sme/facts-figures analysis/eurobarometer/fl283_ en.pdf s. 4.

${ }^{8}$ Flash Eurobarometer, Entrepreneurship ... op. cit., 2009, s. 136; Flash Eurobarometer, Entrepreneurship in the EU and beyond. Analytical Report, Series 354, 2012, http://ec.europa.eu/ public_opinion/flash/fl_354_en.pdf s. 31-34. 
- odsetka osób, które preferowałyby własną działalność gospodarczą (2012 - 47\% - PL, 37\% - UE; 2009 - 49\% - PL 45\% - UE) ${ }^{9}$.

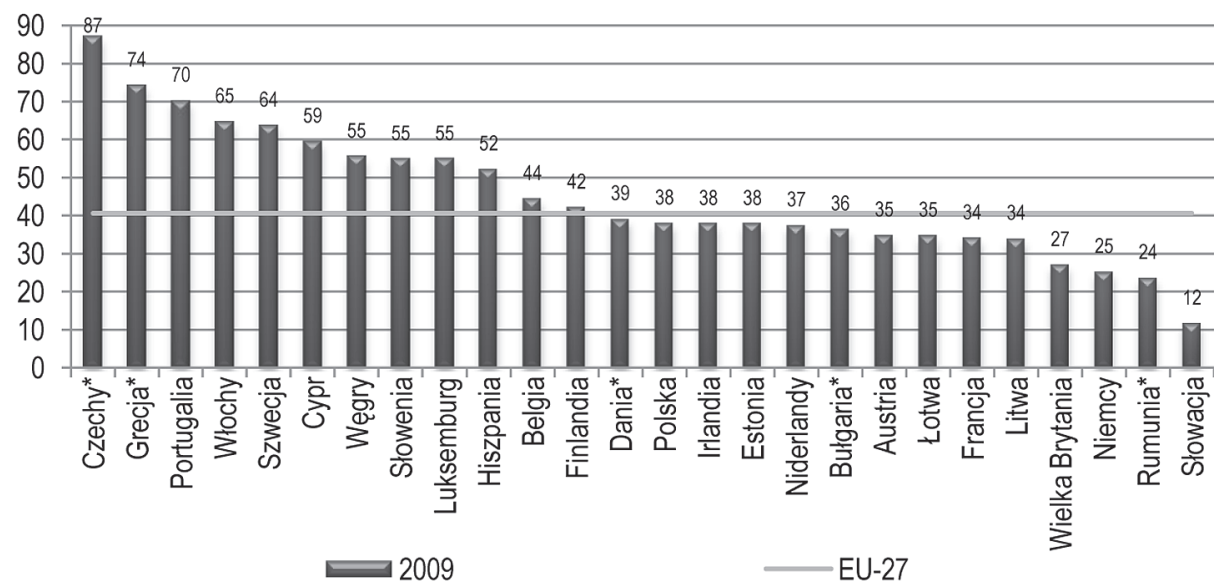

Wykres 1. Liczba podmiotów gospodarczych przypadających na 1 tys. mieszkańców w krajach UE-27 w roku 2009

* - ostatnie dostępne dane za rok 2008.

Źródło: opracowanie własne na podstawie Eurostat - Structural Business Statistics, http://epp.eurostat.ec.europa.eu/ portal/page/portal/statistics/search_database (12.05.2011).

$\mathrm{Z}$ jednej strony społeczności na całym świecie, w tym również Polacy, uznają przedsiębiorców za kreatorów i wizjonerów, tworzących nowe miejsca pracy $(87 \%-2012,87 \%-2009)$ oraz nowe produkty i usługi, które służą wszystkim obywatelom $(79 \%-2012,78 \%-2009)^{10}$. Nie można jednak zapominać o tym, iż w ostatnich latach wizerunek przedsiębiorcy stracił na znaczeniu. Większa część Europejczyków (52\% - 2012, 53,6\% - 2009) uważa, że przedsiębiorcy kierują się jedynie własnymi korzyściami materialnymi. W roku 2009 blisko połowa (49,5\%) uznała, że przedsiębiorcy wykorzystują swoich pracowników, podczas gry w roku 2012 już zdecydowana większość opowiedziała się za tym wariantem $-58 \%$ odpowiedzi ${ }^{11}$. Niepokojem napa-

${ }^{9}$ Flash Eurobarometer, Entrepreneurship ..., op. cit., 2009, s. 111; Flash Eurobarometer, Entrepreneurship ..., op. cit., 2012, s. 15-17.

${ }^{10}$ W przypadku UE-27 - 78,4\% (2009) ankietowanych uznało, że przedsiębiorcy tworzą produkty i usługi, które służą innym obywatelom (wariant zdecydowanie zgadzam się i zgadzam się), w Polsce te kategorie odpowiedzi wybrało 79,2\% respondentów; Flash Eurobarometer, Entrepreneurship ... op. cit., 2009, s. 111; Flash Eurobarometer, Entrepreneurship ... op. cit., 2012, s. 222-223; 226-227.

${ }_{11}$ Flash Eurobarometer, ... op. cit., 2009, s. 130-134; Flash Eurobarometer, Entrepreneurship ... op. cit., 2009, s. 111; Flash Eurobarometer, Entrepreneurship ..., op. cit., 2012, s. 97, 224-225, 228- 
wa fakt, że dane te uległy znacznemu pogorszeniu w stosunku do badania $\mathrm{z}$ roku $2007^{12}$ (42,4\% dla wariantu przedsiębiorcy wykorzystują swoich pracowników i 45,4\% dla wariantu przedsiębiorcy kierują własnymi korzyściami materialnymi $)^{13}$. Wizerunek polskiego przedsiębiorcy jest jeszcze mniej pochlebny niż przeciętnego przedsiębiorcy europejskiego. W roku 2012 aż 56\% polskich respondentów $(63,4 \%$ - 2009) uznało, że przedsiębiorca to osoba dbająca jedynie o własne zyski. Dodatkowo, 91\% respondentów wskazało, że przedsiębiorca zaspokajając własne korzyści, wykorzystuje swoich pracowników $\left(69,5 \%\right.$ - 2009 ankietowanych) ${ }^{14}$.

2. Postawa przedsiębiorcza obywateli - Polska na tle UE

Zdecydowanemu pogorszeniu uległa proprzedsiębiorcza postawa obywateli zamieszkujących kraje unijne. Według badania z roku 2012 jedynie 37\% mieszkańców UE jest zainteresowanych prowadzeniem własnej działalności gospodarczej (wykres 2.). Pracę etatową wybrałoby aż 58\% ankietowanych, podczas gdy w poprzedniej edycji badania było to $49 \%$ respondentów ${ }^{15}$, co dawało wynik na poziomie podobnym do wyników z roku 2007. W tym zakresie występują istotne różnice pomiędzy poszczególnymi państwami członkowskimi. Pracę na etacie znacznie częściej wybierali mieszkańcy Szwecji (74\%) czy Finlandii (73\%), najmniejsze zainteresowanie pracą etatową wykazywali obywatele Litwy (32\%), Bułgarii (40\%) i Grecji (43\%). Polska (50\%) znalazła się w grupie tych, spośród 12 krajów unijnych, w których preferencje wobec zatrudnienia na etacie były poniżej średniej unijnej. Warto jednak podkreślić, iż w porównaniu do badań z roku 2004, 2007 oraz 2009 zainteresowanie Polaków własną działalnością gospodarczą spada - z 51\% (2004, 2007) najpierw do 49\% (2009) a obecnie nawet do 47\% (2012) ${ }^{16}$.

W dalszej części raportu Eurobarometru odnajdujemy informacje potwierdzające fakt, iż większe zainteresowanie samozatrudnieniem wykazują mężczyźni (2012 - 42\%, 2009 - 51\%) aniżeli kobiety (2012 - 33\%, 2009 39\%), podobnie jak młodzi mieszkańcy aniżeli starsze grupy społeczne, osoby

229.

${ }^{12} \mathrm{~W}$ badaniu przeprowadzonym w roku 2007 uczestniczyło 25 krajów UE, zatem podana wartość średnia dotyczy UE-25.

${ }^{13}$ Flash Eurobarometer, Entrepreneurship Survey of the EU (25 Member States), United States, Iceland and Norway Analytical Report, Series 192, 2007 http://ec.europa.eu/public_opinion/ flash/fl_192_en.pdf s. 36.

${ }^{14}$ Flash Eurobarometer, Entrepreneurship ..., op. cit., 2009, s. 111; Flash Eurobarometer, Entrepreneurship ..., op. cit., 2012, s. 224-225, 228-229.

${ }^{15}$ W 2009 roku próba badawcza liczyła 19635 osób, z czego 8856 zadeklarowało chęć prowadzenia własnej działalności, podczas gdy 9638 osób wybrało zatrudnienie etatowe.

${ }_{16}$ Flash Eurobarometer, ... op. cit., 2009, s. 14; Flash Eurobarometer Entrepreneurship ... op. cit., 2007 http://ec.europa.eu/public_opinion/flash/fl_192_en.pdf s. 7. 
z wyższym wykształceniem aniżeli osoby kończące edukację na niższym poziomie i osoby nadal uczące się ${ }^{17}$.

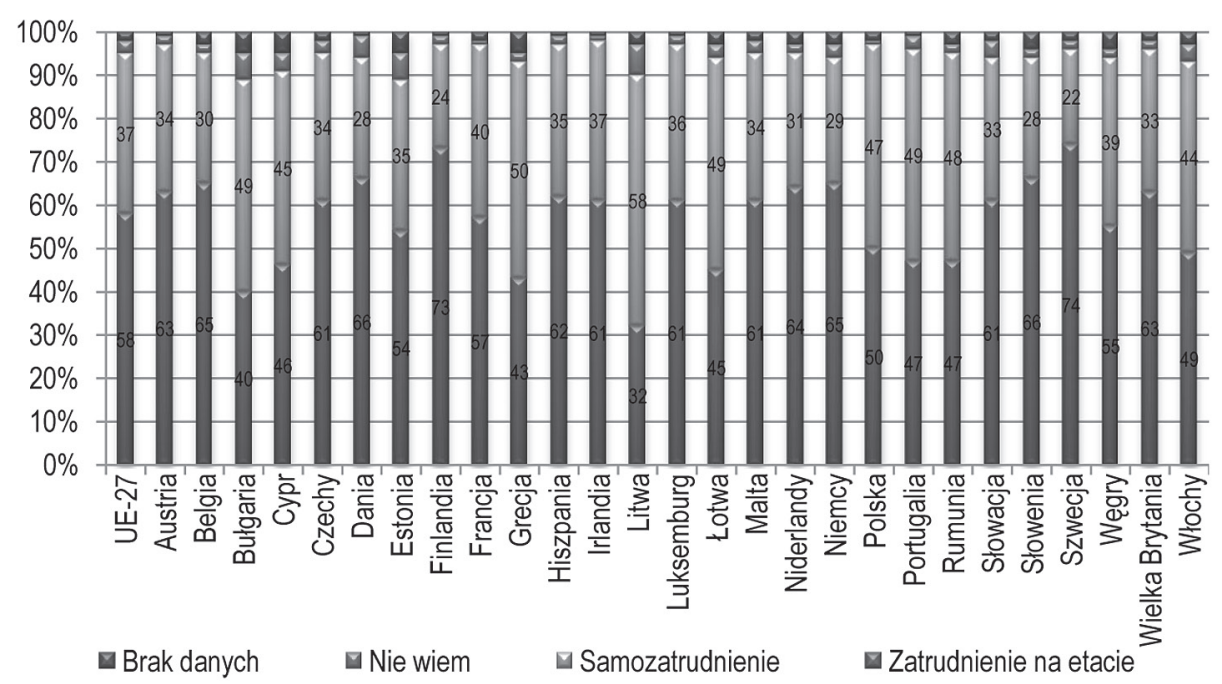

Wykres 2. Preferencje obywateli UE-27 w zakresie formy zatrudnienia w roku 2012.

Źródło: opracowanie własne na podstawie Flash Eurobarometer, nr 354, 2012.

Droga zawodowa obrana przez rodziców stanowi również istotny wyznacznik dla preferencji zawodowych dzieci. W rodzinach, w których jeden z rodziców prowadził własną działalność gospodarczą, 55,8\% dzieci deklarowało chęć posiadania własnego biznesu. Podczas gdy w rodzinach, w których nie było tradycji przedsiębiorczych, jedynie $41,8 \%$ dzieci wyrażało chęć samozatrudnienia ${ }^{18}$.

W Polsce, podobnie jak i w całej UE, czynniki, które decydują o wyborze zatrudnienia etatowego, związane są ze stabilizacją związaną ze stałym źródłem dochodu (2012 - 29\% - PL, 24\% - UE; 2009 - 44,2\% - PL, 40,2\% - UE) i pewnością zatrudnienia (2012 - 26\% - PL, 27\% - UE; 2009 - 41,35\% - PL, 35,1\% - UE). Równie ważnymi motywami wpływającymi na wybór pracy na etacie są warunki zatrudnienia rozumiane jako stałe godziny pracy $(2012$ - 13\% - PL, 11\% - UE; 2009 - 20,6\% - PL, 16,1\% - UE) i zabezpieczenie socjalne $(2012$ - 12\% - PL, 9\% - UE; 2009 - 16,6\% - PL, $13,2 \%$ - UE). W roku 2012 dodatkowo blisko $1 / 3$ respondentów wskazywała na wariant „Inne”. Trudności w prowadzeniu własnego biznesu czy też brak

${ }_{17}$ Flash Eurobarometer, Entrepreneurship ... op. cit., 2012, s. 18.

${ }^{18}$ Flash Eurobarometer, Entrepreneurship ... op. cit., 2009, s. 111. 
odpowiednich środków finansowych lub niewystarczające kwalifikacje mają znacznie mniejsze znaczenie (por. wykres 3.).
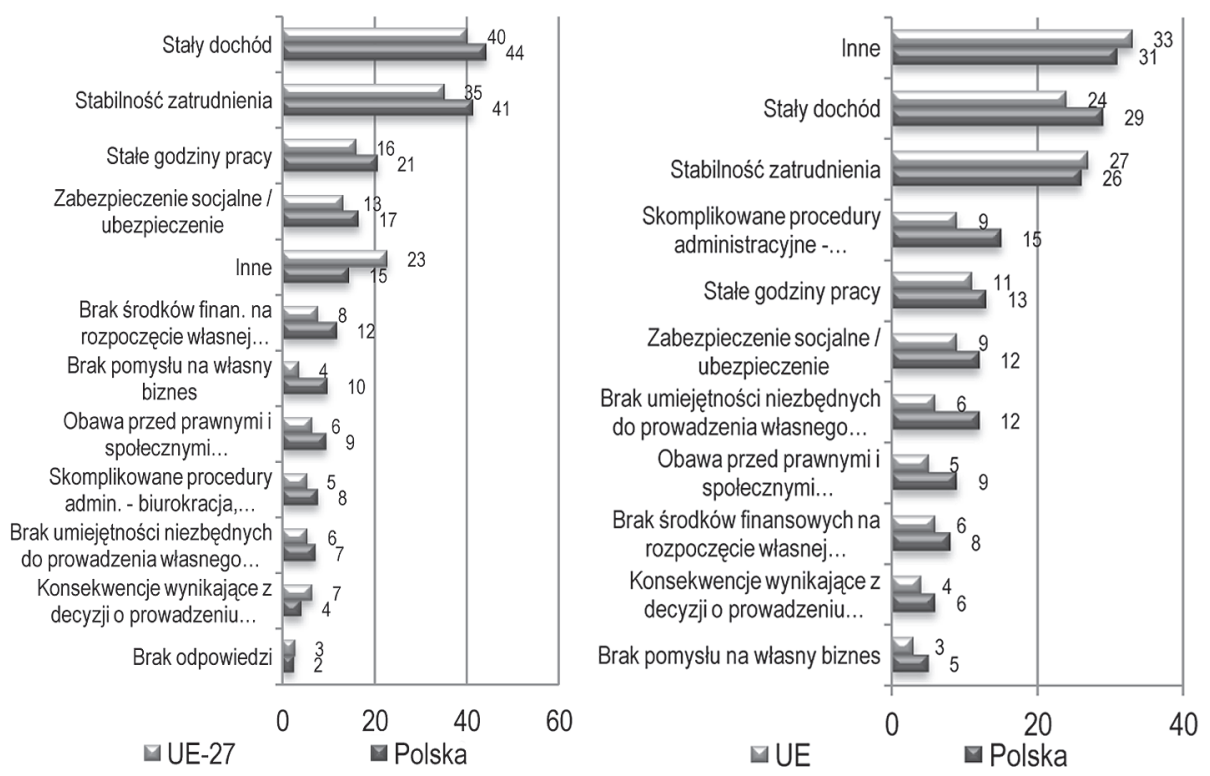

Wykres 3. Preferencje mieszkańców UE w zakresie pracy na etacie, Polska na tle pozostałych państw członkowskich

2009 r. wykres lewy, 2012 r. wykres prawy.

Źródło: opracowanie własne na podstawie Eurobarometer Survey on Entrepreneurship, 2009, 2012 http://ec.europa. eu/enterprise/policies/sme/facts-figures-analysis/eurobarometer/fl283_en.pdf ( 10.09.2011).

Mając na uwadze preferencje związane z pracą na własny rachunek, wyniki uzyskane dla Polski, podobnie jak dla całej UE, ulegają pogorszeniu. W roku 2009 w Polsce więcej ludzi wolałoby prowadzić własny biznes (49,2\%), niż pracować u kogoś $(42,8 \%)$ - uzyskany wynik jest lepszy od średniej unijnej ${ }^{19}$. Podczas gdy w roku 2012 pracę na etacie wybrało 50\% respondentów, a prowadzenie własnego biznesu $47 \%$, nadal daje to wynik powyżej średniej unijnej, gdzie 58\% opowiedziało się za pracą na etacie. Polacy cenią przede wszystkim niezależność i możliwość samorealizacji, co bezpośrednio utożsamiają z pracą na swoim - to decydujący argument dla 65\% ankietowanych $(2009-71,4 \%)$.

${ }^{19}$ W roku 2009 próba badawcza w przypadku Polski liczyła 1005 osób, przy czym na pytanie dotyczące preferencji w sferze zatrudnienia poprawnych odpowiedzi udzieliło 924 respondentów, 430 osób wybrało zatrudnienie etatowe, podczas gdy 494 osoby opowiedziały się za prowadzeniem własnej działalności gospodarczej. 
Wizja lepszych zarobków jest zdecydowanie mniej ważna dla Polaków (2012 - 24\%, 2009 - 32,1\%), chociaż ma ona zdecydowanie większe znaczenie niż dla przeciętnego Europejczyka (średnia dla UE-27 wynosi 20,2\% - 2009, $16 \%-2012)^{20}$ (por. wykres 4.).
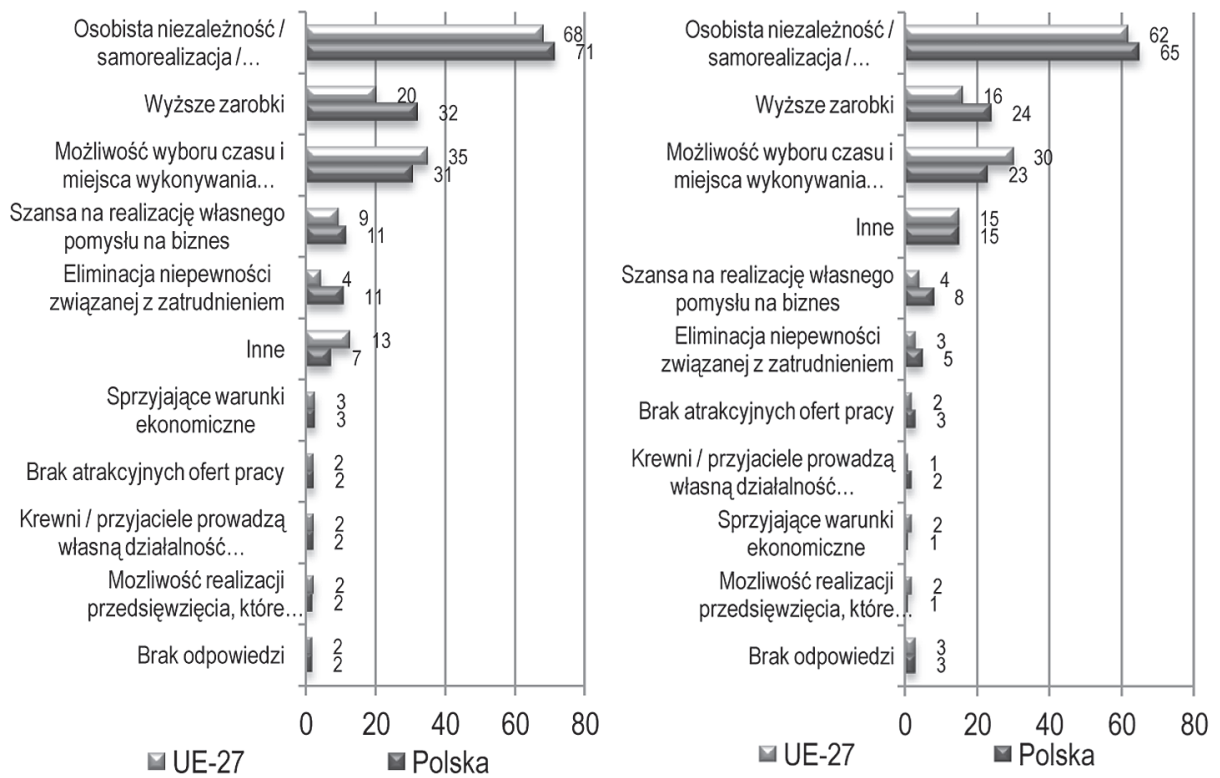

Wykres 4. Preferencje Europejczyków w zakresie pracy na własny rachunek (dane dla UE-27) 2009 r. wykres lewy, 2012 r. wykres prawy.

Źródło: opracowanie własne na podstawie Eurobarometer Survey on Entrepreneurship, 2009, http://ec.europa.eu/enterprise/policies/sme/facts-figures-analysis/eurobarometer/fl283_en.pdf (10.09.2011).

Potencjał przedsiębiorczy ankietowanych został określony na podstawie dwóch kategorii:

- możliwości samozatrudnienia w okresie nie dłuższym niż 5 lat,

— doświadczenia w prowadzeniu własnej działalności gospodarczej.

W obu przypadkach Polacy wykazują się większą zdolnością do podejmowania własnej inicjatywy przedsiębiorczej aniżeli przeciętny Europejczyk. I tak 36\% Polaków, spośród tych, którzy nigdy nie byli samozatrudnieni, deklaruje że możliwość przejścia na swoje jest realna. To wynik znacznie lepszy niż średnia dla UE-27, która wynosiła 28,1\% w roku 200921. (Flash Eurobarometer nr 283 December 2009, s. 116). Według wielu z osób, które do tej

${ }^{20}$ Flash Eurobarometer, Entrepreneurship..., op. cit., 2009, s. 114.

${ }^{21}$ Flash Eurobarometer, Entrepreneurship... op. cit., 2009, s. 116. 
pory nie prowadziły własnej działalności gospodarczej, przejście na swoje to całkiem realny plan. $\mathrm{O}$ założeniu biznesu myśli lub podjęło już w tym kierunku jakieś działania blisko $1 / 3$ polskich respondentów $(32,5 \% \mathrm{z} n=759)$. Średnia dla UE-27 jest niższa - w uruchomienie własnego biznesu wierzy 31,3\% Europejczyków $(n=15103)^{22}$.

\section{ZAKOŃCZENIE}

Europa stoi przed ogromnym wyzwaniem, jakim jest wyjście z kryzysu gospodarczego oraz ustabilizowanie sytuacji w krajach strefy euro. W konsekwencji istnieje potrzeba stymulowania przedsiębiorczości w poszczególnych krajach członkowskich. Więcej przedsiębiorców to więcej nowych miejsc pracy, większa konkurencyjność i poprawa sytuacji ekonomicznej oraz społecznej kraju. W chwili obecnej w UE jedynie 37\% ankietowanych zadeklarowało chęć prowadzenia działalności gospodarczej na własny rachunek. Respondenci zdecydowanie preferowali zatrudnienie etatowe wobec prowadzenia samodzielnie biznesu. Dla porównania w Stanach Zjednoczonych i Chinach połowa respondentów jest zainteresowana własną działalnością gospodarczą. Polska na tym tle wypada również mało korzystnie. Przede wszystkim obserwuje się niską wartość liczby podmiotów gospodarczych przypadających na 1 tys. mieszkańców, co plasuje Polskę daleko poza czołówką UE. Dodatkowo spada odsetek osób zainteresowanych prowadzeniem własnej działalności gospodarczej, niemniej jednak zainteresowanie zgłaszane przez mieszkańców Polski jest nadal większe aniżeli średnia dla UE.

Potrzeba prowadzenia działań wspierających przedsiębiorczość została już wiele lat temu wyartykułowana przez Komisję Europejską. Dziś, dziesięć lat po opublikowaniu Przedsiębiorczośc w Europie. Zielona Ksiegga instytucje europejskie bardziej niż kiedykolwiek wcześniej podkreślają konieczność stymulowania przedsiębiorczości. Plan działania - Przedsiębiorczość $2020^{23}$ przewiduje:

- wsparcie edukacji przedsiębiorczości w szkołach celem zainteresowania młodych ludzi prowadzeniem własnego biznesu, bardziej aniżeli czekaniem na interesującą propozycję, która może, ale nie musi przyjść z rynku pracy;

- skrócenie czasu potrzebnego do uruchomienia własnej działalności gospodarczej oraz uzyskania niezbędnych pozwoleń;

- usprawnienie procedur związanych z postępowaniem upadłościowym;

${ }^{22}$ Flash Eurobarometer, Entrepreneurship... op. cit., 2009, s. 139.

${ }^{23}$ Por. European Commission, Citizens' Summary. Entrepreneurship 2020 - EU Action Plan. 
- rozwój instrumentów wsparcia, zwłaszcza dla kobiet, osób starszych, imigrantów oraz bezrobotnych.

Komisja Europejska zmierza przede wszystkim do uproszczenia procedur administracyjnych związanych $\mathrm{z}$ uruchomieniem własnej działalności gospodarczej. Dodatkowo mają się pojawić programy szkoleniowe, doradcze oraz mentoring dla tych, którzy planują bądź już prowadzą przedsiębiorstwo.

\section{BIBLIOGRAFIA}

European Commission, Communication from the Commission to the European Parliament, the Council, the European Economic and Social Committee and the Committee of the Regions. Entrepreneurship 2020 Action Plan. Reigniting the entrepreneurial spirit in Europe, Brussels, 9.1.2013 COM(2012) 795 final, 2013 http://eur-lex.europa.eu/LexUriServ/LexUriServ.do?uri=COM:2012:0795:FIN:e $\mathrm{n}: \mathrm{PDF}$.

European Commission, Citizens' Summary. Entrepreneurship 2020 - EU Action Plan, $2013 \mathrm{http} / /$ ec.europa.eu/enterprise/policies/sme/public-consultation/files/ap_citizen_summary_en.pdf.

European Communities, Facing the Challange. The Lisbon Strategy for Growth and Employment, Report from the High Level Group, Office for Official Publications of the European Communities, Luxembourg 2004, http://europa.eu.int/comm/lisbon_strategy/index_en.html.

European Communities, Green Paper. Entrepreneurship in Europe, COM(2003) 27 final, Brussels 21.03.2003, http://eur-lex.europa.eu/LexUriServ/site/en/com/2003/ com2003_0027en01.pdf.

Flash Eurobarometer, Entrepreneurship Survey of the EU (25 Member States), United States, Iceland and Norway Analytical Report, Series 192, 2007, http://ec.europa. eu/public_opinion/flash/fl_192_en.pdf.

Flash Eurobarometer, Entrepreneurship in the EU and beyond. Analytical Report, Series 283, 2009, http://ec.europa.eu/enterprise/policies/sme/facts-figures analysis/ eurobarometer/fl283_en.pdf.

Flash Eurobarometer, Entrepreneurship in the EU and beyond. Analytical Report, Series 354, 2012, http://ec.europa.eu/public_opinion/flash/fl_354_en.pdf.

Główny Urząd Statystyczny (2010), Zmiany strukturalne grup podmiotów gospodarki narodowej w rejestrze REGON, 2011 r., Warszawa, http://www.stat.gov.pl/bdl/ app/strona.html?p_name=indeks. 